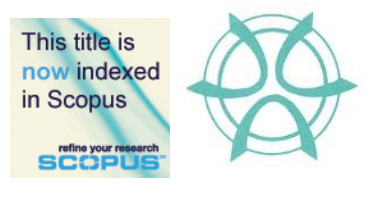

PLANNING MALAYSIA:

Journal of the Malaysian Institute of Planners

VOLUME 16 ISSUE 1 (2018), Page 145 - 154

\title{
SEGREGATED LAND USE SPRAWL: TOD APPROACH FOR MIXED- USE HOUSING DEVELOPMENT IN KUALA LUMPUR
}

\author{
Nur Aulia Rosni', Zakiah Ponrahono ${ }^{2} \&$ Noorzailawati Mohd Noor ${ }^{3}$ \\ ${ }^{1,3}$ Kulliyyah of Architecture and Environmental Design \\ INTERNATIONAL ISLAMIC UNIVERSITY MALAYSIA \\ ${ }^{2}$ Faculty of Environmental Studies \\ UNIVERSITY PUTRA MALAYSIA
}

\begin{abstract}
Spatial analysis of current land use provides useful insight on urban development trend specifically in measuring sprawl growth. Remote sensing and GIS technologies were applied in this research to measure the phases of segregated urban sprawl growth, focusing on the aspect of mixed land use planning. The findings proved that Kuala Lumpur is currently facing segregated land use sprawl based on the measurement derived from one of LUGI component. This type of sprawl transpired within the residential zone in Kuala Lumpur city, demoting mixed-use development by unravelling different classes of land uses into singleuses, thus promoting high dependency on motorised vehicle and discouraging public and pedestrian modes of transportation. The transit-oriented development is one of necessary approaches to control segregated sprawl and promotes mixeduse development in housing areas within the city.
\end{abstract}

Keywords: segregated land use sprawl, urban sprawl, remote sensing and GIS, transit-oriented development, mixed-use development 
PLANNING MALAYSIA

Journal of the Malaysia Institute of Planners (2018)

\section{INTRODUCTION}

Segregated land use typically consists of single use of land within a specific distance and is considered as sprawling by many researchers (Burchell \& Mukherji, 2003; Burchell, Shad, Listokin, \& Phillips, 1998; Enid, 2006; Ewing, 1997; Ewing, Pendall, \& Chen, 2002; Galster et al., 2001; Haines \& McFarlane, 2007; Hasse \& Lathrop, 2003; Hasse \& Kornbluh, 2004; Jiang, Liu, Yuan, \& Zhang, 2007). The development of mixed-use residential zone within the city helps to reduce segregated sprawl growth in the area, provide a variety of affordable housing and reverse urban gentrification. Moreover, mixed-use housing area creates a safer and liveable environment for its residents.

Segregated land use sprawl reduces functionality and efficiency of diverse land uses and promotes high dependency on private vehicles to commute and access other land uses (Arbury, 2005; Hamidi \& Ewing, 2014; Travisi, Camagni, \& Nijkamp, 2009). Segregated land characterises urban sprawl where the area is dominated by automobiles (Haines \& McFarlane, 2007). However, as mentioned by Arbury (2005), one factor alone cannot lead to urban sprawl, asserting that segregated, leapfrog or low density alone does not cause sprawl, but the combination of each factor with consideration of its effect on other factors are important determinants of whether an area is 'sprawled' or not. Yue, Zhang and Liu (2016) argue that low-density, single-use, and leapfrog development may result in the segregation of land uses. Therefore, measuring the degree of mixed land use is an important step to control segregated sprawl through effective land use planning implementation (Ewing et al., 2002).

The objective of this research is to measure segregated land use sprawl using remote sensing and GIS application, and to propose the Transit Oriented Development (TOD) approach to encourage mixed-use development in Kuala Lumpur sprawling housing area to reduce sprawl and negative impacts on the environment.

\section{THEORIES AND DEFINITIONS}

\section{Mixed Use Development}

Mixed-use development is the mixture of land uses within the same geographical setting of human interactions with the resource available (Nabil, Elsayed, \& Eldayem, 2015). It is an optimisation of land availability into a broad segment of uses. It is widely adopted as land use approach in addressing the issues of zoning and segregated land uses. Land and property value of the area can be controlled, where adjustment of city system monitoring and planning implementation become more efficient. The compactness of land uses within effective and productive radius giving more profitable economic model of the area. Hence, the uniformity of population, residential and infrastructure are achievable (Vorontsova, Vorontsova, \& Salimgareev, 2016). 
Nur Aulia Rosni, Zakiah Ponrahono \& Noorzailawati Mohd Noor

Segregated Land Use Sprawl: TOD Approach for Mixed-Use Housing Development in Kuala Lumpur

\section{Segregated Land Use Sprawl}

There are quite a number of researchers who have expressed opinions that segregated land use sprawl is mainly the result of the land use and zoning policies adopted by the authorities. According to Arbury (2005), the disastrous analysis of mixing high-density housing and polluting factories in the nineteenth century industrialising cities led to the introduction of zoning laws that facilitate singleuse development in the European countries. After years have passed, those policies have worsened the problems associated with sprawl where the local zoning policies can create the types of land use that seem to matter most to households but causing loss of other valuable land uses in the area (Nechyba \& Walsh, 2004).

Despite this, several scholars have proposed that planners and policymakers could ensure that the development is best leveraged by supporting policies for mixed-use development (Ewing, Hamidi, Grace, \& Dennis, 2016; Steil, Salingaros, \& Mehaffy, 2007). Bart (2010), and Yaping and Min (2009) stressed on the need for better land use policies to stand against urban sprawl, which has caused chaotic situation to evolve, including lower quality of urban space, increasing social segregation, and environmental deterioration.

In this research, the segregated land use sprawl is defined as less than two types of urban land uses beyond the reasonable walking distance to other urban land uses. Barnes, Morgan, Roberge and Lowe (2001) describe segregated land use sprawl as the degree to which residential land uses are removed from employment-generating land uses such as commercial, administrative and industrial land uses. Farther separation between land uses is causing longer commuting distance. Therefore, this research accepts residential, commercial, industrial and institutional area in Kuala Lumpur as the main employmentgenerating land uses to measure the segregated urban sprawl growth in this city.

\section{Transit Oriented Development}

Transit-oriented development (TOD) can be defined as vibrant development concept that promotes seamless connectivity within transit distance with the compactness of land activities (Kimball, Chester, Gino, \& Reyna, 2013). With the main development highlight of the walkable district, high density, transit, nonmotorized dependency, shifting mode, mix use of land and dense network of street and path, TOD is the most effective approach of urban renewal to uniform the segregated land use sprawl of the city.

\section{METHODOLOGY}

\section{Measuring Segregated Land Use Sprawl}

The measurement of segregated land use geospatial indices sprawl in Kuala Lumpur housing area was carried out within the $400 \mathrm{~m}$ walking distance radius 
PLANNING MALAYSIA

Journal of the Malaysia Institute of Planners (2018)

from new residential development patches. The new residential development patches were derived from Land Use Land Cover (LULC) change detection techniques using remote sensing satellite images from two different years (20052015). Through GIS application, the natural features such as water bodies, vacant land and forest reserve area were excluded leaving only human-made land use features to increase the accuracy of estimated mixed value. Arbury (2005) mentioned the harmful effect of mixing the residential and commercial use with industrial area due to the latter environmental effect towards the population in the former land use zones. Nevertheless, this research did not exclude the industrial area in Kuala Lumpur because of the existing planning guidelines in Malaysia have already outlined the types of industrial activities permitted for a particular location. Moreover, Kuala Lumpur City Hall $(\mathrm{KLCH})$, through Kuala Lumpur City Plan 2020 (KLCP 2020), regulates and manage land use development in order to avoid inappropriate land use and activities so as to achieve a healthy and clean built environment where industrial land use were placed in zones according to their permitted land use conditions. As for primary city like Kuala Lumpur, the industrial areas consists of Small and Medium types such as Industrial zones for Small-Medium Enterprise (SME); mixed commercial and industrial land use; as well as Research and Development (R\&D) like industrial parks. By referring to the previous research work, this research modified and developed a set of indicators for segregated land use sprawl as presented in Table 1.

Table 1: Segregated land use sprawl indicators

\begin{tabular}{cll}
\hline Grid Cell Categories & $\begin{array}{c}\text { Parameters } \\
\text { (No. of Land Use) }\end{array}$ & \multicolumn{1}{c}{ Annotation } \\
\hline A & $\leq 2$ & Segregated Land Use Sprawl \\
B & $=3$ & Common Development \\
C & $\geq 4$ & Smart Growth \\
\hline
\end{tabular}

Sources: Modified from Hasse (2004).

The land use segregation sprawl indicators were divided into three categories: category A (Segregated Land Use Sprawl Area consisting of two types of land use and below); category B (Common Development Area which equals to three types of land uses), and category C (Smart Growth Area where a grid cell consist of four types of land uses and more). The Common Development area in this research is being described as either prone to segregated sprawl or smart growth depending on the future instalment of proper planning in this field.

General measurement method includes the conversion of built-up land area within the six Kuala Lumpur Strategic Planning Zones (SPZ) into grid cells with 400 metres cells resolution using the GIS Spatial Analyst tools. By using the overlay analysis techniques, the Kuala Lumpur land use 2015 data layer was overlapped with the $400 \mathrm{~m}$ gridded cells layer to determine the number of land use mix in each grid cells. Then, by using the query and geostatistical tools in 
Nur Aulia Rosni, Zakiah Ponrahono \& Noorzailawati Mohd Noor

Segregated Land Use Sprawl: TOD Approach for Mixed-Use Housing Development in Kuala Lumpur

GIS software, the percentage of grid cells was calculated according to categories that were determined according to the defined segregated land use sprawl indicators. The calculation method for segregated land use sprawl in housing area was conducted by buffering the designated new residential patches in 2015 using the $400 \mathrm{~m}$ radius and were converted into grid cells with $400 \mathrm{~m}$ resolutions. The layer of the buffered residential patches was being overlaid with the gridded cells layer using the GIS spatial analyst tools. All grid cells outside the residential patches buffered radius were eliminated including cells that were being covered only by $1 / 4(25 \%)$ or less. After the data layer cleaning process, the final grid cells layer was overlaid with the Kuala Lumpur land use 2015 data layer to determine the parameters in each grid cell (refer Table 1). The query and geostatistical tools were used to calculate the percentage of the grid cells according to the category of the indicators.

The segregated land use sprawl ( $\mathrm{SL}_{\mathrm{Res}}$ ) was calculated using the formula modified from Hasse (2004) as shown below:

$$
\left(\mathrm{SS}_{\mathrm{spz}}\right) \frac{\sum \mathrm{GC}_{\mathrm{x}}}{\sum \mathrm{GCUnit}} \times 100
$$

Where:

$\left(\mathrm{SL}_{\text {Res }}\right)=$ Residential segregated land use sprawl

$\left(\mathrm{GC}_{\mathrm{Ind}}\right)=$ Number of grid cell to indicator categories consisting types of land use $\left(\mathrm{GC}_{\text {Unit }}\right)=$ Number of grid cell units

\section{RESULTS AND DISCUSSION}

\section{Findings of Segregated Land Use Sprawl}

The findings from segregated land use sprawl measurement are presented in percentage value as shown in Table 2. Five SPZ in Kuala Lumpur scores high percentage of segregated residential sprawl, and the percentage of segregated sprawling in City Centre SPZ was equivalent to the percentage of common development $(0.39 \%)$.

Damansara-Penchala SPZ scored the highest value of residential segregated land use sprawl with $20.31 \%$ proving this SPZ is having critical issues on segregated sprawl, followed by Sentul-Menjalara SPZ with $17.97 \%$ and Bandar Tun Razak-Sg. Besi SPZ (13.67\%). The key finding from this research confirmed that Kuala Lumpur city is currently facing segregated land use sprawl indicating less mixed-use development within walking distance $(400 \mathrm{~m})$ in the housing area. 
PLANNING MALAYSIA

Journal of the Malaysia Institute of Planners (2018)

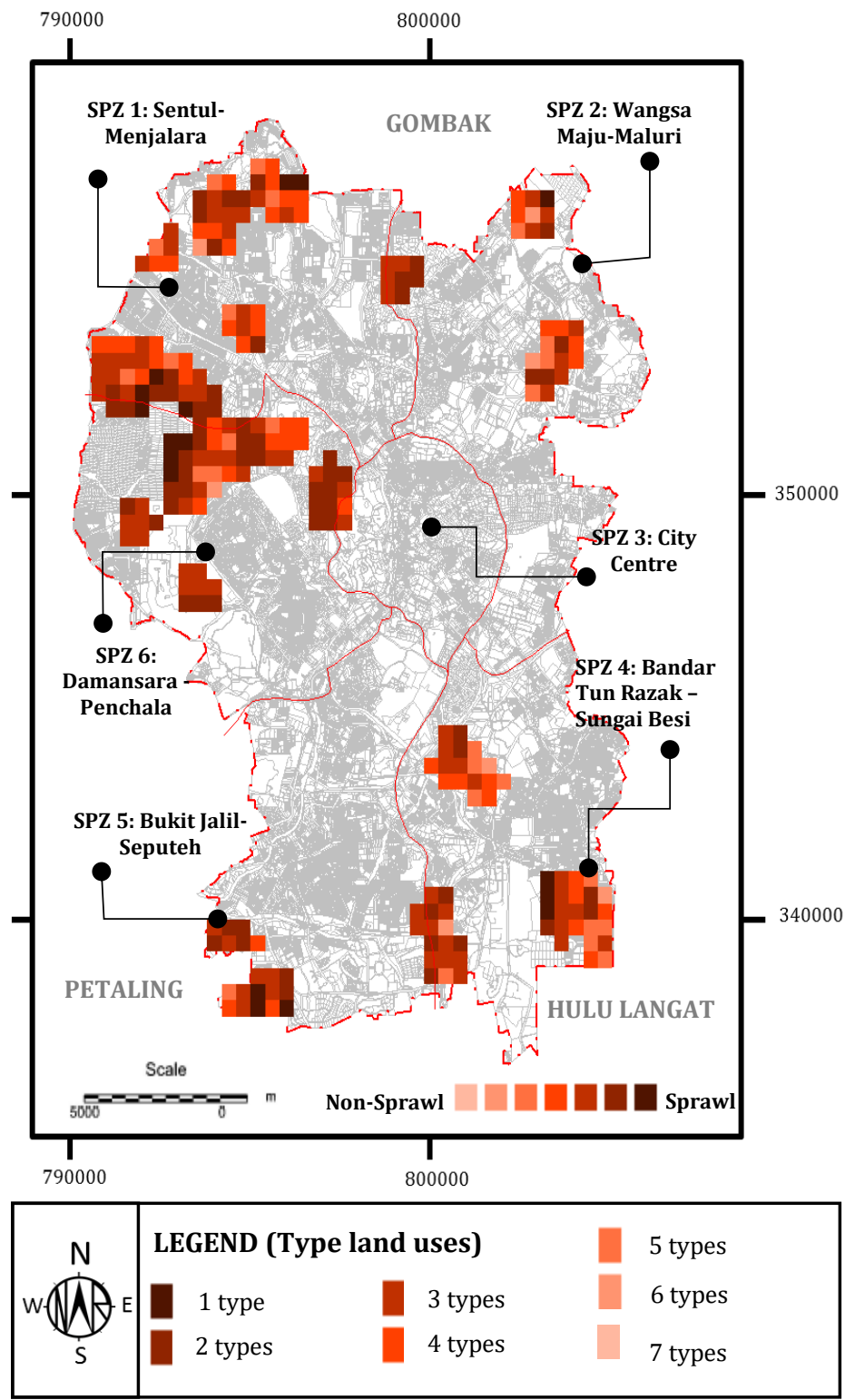

Figure 1: Segregated land use sprawl in Kuala Lumpur housing area 
Nur Aulia Rosni, Zakiah Ponrahono \& Noorzailawati Mohd Noor

Segregated Land Use Sprawl: TOD Approach for Mixed-Use Housing Development in Kuala Lumpur

Table 2: Kuala Lumpur segregated land use sprawl in housing area

\begin{tabular}{|c|c|c|c|c|c|}
\hline \multicolumn{2}{|c|}{ Planning Zones } & Segregated (\%) & $\begin{array}{l}\text { Common } \\
(\%)\end{array}$ & $\begin{array}{l}\text { Smart } \\
\text { Growth (\%) }\end{array}$ & Annotations \\
\hline 1. & Sentul-Menjalara & 17.97 & 9.38 & 3.13 & Sprawl \\
\hline 2. & Wangsa Maju-Maluri & 8.20 & 2.34 & 1.95 & Sprawl \\
\hline 3. & City Centre & 0.39 & 0.39 & 0.00 & Common \\
\hline 4. & $\begin{array}{l}\text { Bandar Tun Razak- } \\
\text { Sg.Besi }\end{array}$ & 13.67 & 3.91 & 5.08 & Sprawl \\
\hline 5. & Bukit Jalil-Seputeh & 6.25 & 1.17 & 0.39 & Sprawl \\
\hline \multirow[t]{2}{*}{6.} & Damansara-Penchala & 20.31 & 3.52 & 1.95 & Sprawl \\
\hline & TOTAL & 66.80 & 20.70 & 12.50 & Sprawl \\
\hline
\end{tabular}

Kuala Lumpur current land use pattern has been the result of previous development practices and trends which were based on single land use zoning (Kuala Lumpur City Hall, 2011). Changes in market forces, trends and focus, coupled with environmental and climatic concerns, require a new and integrated approach towards the diversified land use planning and spatial developments. Therefore, there is a need to look at a more flexible approach towards land use zoning and the manner in which developments are carried out within Kuala Lumpur. On first sight, it might seem implausible to argue that such compact and dynamic urban area like Kuala Lumpur is facing single-use urban sprawl. However, considering the fact stated by Kuala Lumpur City Hall (2011), most of the suburban areas in Kuala Lumpur are currently facing segregated types of sprawl due to the single land use zoning policies previously adopted.

In this research, the geospatial indices model of segregated land use sprawl distinguishes single-use development pattern (segregated land use) from mixed and common land use development pattern. However, rather than using single land use characteristic to denote this type of sprawl, this research ascertains less than two types of land use within specified walking distance as segregated sprawl. While the common development types are walking distance catchment area with three types of land uses followed by mixed development (four types of land uses and above).

The findings indicate that Kuala Lumpur experiences segregated sprawl, which is the result of the previous land use regulation and policies. This trend is not something peculiar since many countries are also facing segregated sprawl due to ineffectual planning policies. The deterring land use and building codes in cities have curbed housing construction which eventually affecting housing supply, leading to increasing housing costs and deepened inequality in urban centres (Florida, 2016).

Based on the findings of this research, segregated sprawl is lower in the city centre as compared to other SPZ. This is because KLCH has introduced many mixed-use zones in their city plan 2020 focusing on the city centre. Moreover, 
PLANNING MALAYSIA

Journal of the Malaysia Institute of Planners (2018)

most states in Malaysia have adopted a set of planning guidelines that caters for the provision of each type of land use according to its regulated proportion. This planning guidelines are seen as effort to discourage segregated sprawling. However, they do not cater for walkable distance, but focused more on big development area. There are many issues arisen from the execution of these guidelines.

\section{TOD Approach to Segregated Land Use Sprawl}

Segregation in the built environment has been studied from many different perspectives including physical land use pattern (housing supply, mobility, accessibility), socioeconomic (social, population income, employment, public health) as well as the environment (pollution, urban heat, carbon footprint, etc.). Nevertheless, the most dominant standpoints of the segregated sprawl development always related back to the spatial factors that shape the social, economic and cultural. Moreover, Wu (2006) states that the spatial heterogeneity of environmental amenities is shown to cause economic segregation across communities and the landscape, with high-income households living in areas with higher level of environmental amenity and better public services.

Poor connection and harmonization between land use elements may adversely affect property value. Uncontrolled population density from the segregation may generate more local traffic, congestion and crime that contribute to low quality of life and inefficient property management. Segregation also can reduce the availability of affordable housing when the divided segment of land are monopolized by private landowners. Additionally, inefficient distribution of land and failure to reduce space between and around developments lead to fragmentation of the habitats that are left after the development.

Segregated land use sprawl in Kuala Lumpur has encouraged traffic congestion and development of roads that lead to strip sprawl. This statement is supported by Bart (2010) when he asserts that the dispersal of home, work and leisure facilities have resulted in increased transport demand. Barnes et al. (2001) and Yue et al. (2016) state that poor accessibility and highly separated land uses causing longer commuting distances between homes and employment.

Kuala Lumpur is an old city, which was established before the instalment of proper planning practice. However, Kuala Lumpur also is a fast growing city in Malaysia, thus providing an opportunity for some of the modern planning concepts to be installed to encourage mixed land uses. The New Urbanism, which involves an attempt to create higher density in traditional settlements with a mix of land uses to promote community and transit use has been experimented and implemented in the United States. This planning concept can be implemented in earliest settlement area in Kuala Lumpur especially in the City Centre, Wangsa Maju-Maluri, and Sentul-Menjalara SPZ. This concept refers to the notion of urban renewal, which points up as a primary objective to 'rebuild the city in the 
Nur Aulia Rosni, Zakiah Ponrahono \& Noorzailawati Mohd Noor

Segregated Land Use Sprawl: TOD Approach for Mixed-Use Housing Development in Kuala Lumpur

city'. This urban policy comes exactly to stand against two logics: the noncontrolled expansion of the cities and the deepening of social inequalities within spatial segregation. It also stands as a new model for the development of city, aiming at saving space and energy, regenerating the degraded urban territories and increasing social diversity. Additionally, mixed types of residential development also encourages less sprawl to the suburban area (leapfrog sprawl), provides housing with different level of affordability and reversing urban gentrification trend.

TOD is sprouting as a major solution to urban sprawl issues in city land, as it provides the optimum benefit of resource management. It is not only about arbitrary nodes which are represented by the $400 \mathrm{~m}$ circles drawn around public transport stops or station, but also tend to support the use of public transport in the urban area. To ensure an urban transit system works effectively, transit stations should be planned to effectively increase the quality of the city by creating a vibrant mix of activities relating to its urban context. Furthermore, TOD concept prioritizes the non-motorized transport networks such as cycling that help in reducing carbon footprint. It provides high connectivity in which it creates dense networks of streets and paths such as pedestrian pathways, bus lanes, and bicycle lanes which are interconnected to give higher accessibility and connectivity to reach a destination.

Another related movement toward controlling segregated sprawling is the push to create a transit-oriented design in which high-density mixed-use developments are planned near transit stations. Less segregated area creates a safer environment which causes the area to be alive all the time. The TOD concept is able to increase pedestrian activity and provides 24-hour passive surveillance through mixed-use development. Kuala Lumpur is now enhancing its public transportation services with the expansion of LRT network and development of new MRT stations, thus, encouraging mixed development in TOD's area will help to lessen the segregated sprawl in Kuala Lumpur. Moreover, by promoting a wide variety of housing types, TODs have the potential to increase housing affordability within close proximity to the central city, reversing the trend of young working families being forced to locate far from the central city due to prohibitively expensive accommodation and therefore being forced into lengthy daily commutes (Arbury, 2005).

\section{CONCLUSION}

The application of earth observation technologies such as remote sensing and GIS is seen as a forerunner for measuring urban sprawl. It is an important step to measure urban sprawl since it is a problem that suffers from uncertainty. The use of such technologies have shown to measure sprawl in Kulala Lumpur has shown that segregated land use sprawl is common in many old and new towns in Kuala Lumpur. The degree of segregated land use sprawl identified in this study shows 
around $13-20 \%$ of housing area in Kuala Lumpur has less mixed-development of land use within $400 \mathrm{~m}$ walking distance. It is thus proposed that TOD application to be encouraged in Kuala Lumpur to alleviate growth of segregated urban sprawl and its impacts.

\section{ACKNOWLEDGEMENT}

The authors are grateful especially to the International Islamic University Malaysia, Universiti Putra Malaysia, anonymous reviewers and other contributors in improving this article. The authors are especially indebted to the Malaysia Remote Sensing Agency (ARSM) for the digital land use satellite imagery database. The authors would like to mention International Institute for Applied System Analysis (IIASA), Academy of Sciences Malaysia (ASM) and Kumamoto National Institute of Technologies (KOSEN) for the opportunity to join their programmes, thus provide knowledge and valuable experience contributing to this research.

\section{REFERENCES}

Arbury, J. (2005). From urban sprawl to compact city - An analysis of urban growth management in Auckland. University of Auckland.

Barnes, K. B., Morgan, J. M., Roberge, M. C., \& Lowe, S. (2001). Sprawl development: Its patterns, consequences, and measurement. Baltimore, Maryland.

Bart, I. L. (2010). Urban sprawl and climate change: A statistical exploration of cause and effect, with policy options for the EU. Land Use Policy, 27(2), 283-292.

Burchell, R. W., \& Mukherji, S. (2003). Conventional development versus managed growth: The costs of sprawl. American Journal of Public Health, 93(9), 1534-1540.

Burchell, R. W., Shad, N. A., Listokin, D., \& Phillips, H. (1998). The cost of sprawl Revisited. Washington, D.C.: Transportation Research Board.

Enid, S. (2006, September). The impact of municipal finance and governance on urban sprawl. In International Symposium on Urban Impacts:Global Lessons for the Great Lakes Basin. September 25-26, 2006, Chicago, Illinois.

Ewing, R. (1997). Is Los Angeles-style sprawl desirable? Journal of the American Planning Association, 63(1), 107-126.

Ewing, R., Hamidi, S., Grace, J. B., \& Dennis, Y. W. (2016). Does urban sprawl hold down upward mobility? Landscape and Urban Planning, 148, 80-88.

Ewing, R., Pendall, R., \& Chen, D. (2002). Measuring sprawl and its impact. Washington DC: Smart Growth America.

Florida, R. (2016). How zoning restrictions make segregation worse. Retrieved from https://www.citylab.com/ equity/2016/01/how-zoning-restrictions-makesegregation-worse/422352/

Galster, G., Hanson, R., Ratcliffe, M. R., Wolman, H., Coleman, S., \& Freihage, J. (2001) Wrestling sprawl to the ground: Defining and measuring an elusive concept. Housing Policy Debate, 12(4), 681-717.

Haines, A., \& McFarlane, D. (2007, October). Understanding landscape fragmentation and parcelization: An examination of traditional planning tools. In 48th Annual 
Nur Aulia Rosni, Zakiah Ponrahono \& Noorzailawati Mohd Noor

Segregated Land Use Sprawl: TOD Approach for Mixed-Use Housing Development in Kuala Lumpur

Conference of the American Collegiate Schools of Planning. October 18-21, 2007, Milwaukee, WI.

Hamidi, S., \& Ewing, R. (2014). A longitudinal study of changes in urban sprawl between 2000 and 2010 in the United States. Landscape and Urban Planning, 128, 72-82.

Hasse, J. E. (2004). A geospatial approach to measuring new development tracts for characteristic of sprawl. Landscape Journal, 23(1), 1-4.

Hasse, J. E., \& Lathrop, R. G. (2003). Land resource impact indicators of urban sprawl. Applied Geography, 23(2-3), 159-175.

Hasse, J., \& Kornbluh, A. (2004). Measuring accessibility as a spatial indicator sprawl. Middle States Geographer, 37, 108-115.

Jiang, F., Liu, S., Yuan, H., \& Zhang, Q. (2007). Measuring urban sprawl in Beijing with geo-spatial indices. Journal of Geographical Sciences, 17(4), 469-478.

Kimball, M., Chester, M., Gino, C., \& Reyna, J. (2013). Assessing the potential for reducing life- cycle environmental impacts through transit-oriented development infill along existing light rail in Phoenix. Journal of Planning Education and Research, 33(4), 395-410.

Kuala Lumpur City Hall. (2011). Draft Kuala Lumpur City Plan 2020. Kuaa Lumpur: Percetakan Nasional Malaysia Berhad.

Nabil, N. A., Elsayed, G., \& Eldayem, A. (2015). Influence of mixed land-use on realizing the social capital. HBRC Journal, 11(2), 285-298.

Nechyba, T. J., \& Walsh, R. P. (2004). Urban sprawl. Journal of Economic Perspectives, $18(4), 177-200$

Steil, L., Salingaros, N. A., \& Mehaffy, M. W. (2007). Growing sustainable suburbs: An Incremental strategy for reconstructing sprawl . In T. Haas (Ed.), New Urbanism \& beyond: Contemporary and future trends in urban design (pp. 1-25). Rizzoli International Publications.

Travisi, C. M., Camagni, R., \& Nijkamp, P. (2009). Impacts of urban sprawl and commuting: A modelling study for Italy. Journal of Transport Geography, 18(3), 382-392.

Vorontsova, A. V, Vorontsova, V. L., \& Salimgareev, D. V. (2016). The development of urban areas and spaces with the mixed functional use. Procedia Engineering, 150, 1996-2000.

Wu, J. (2006). Environmental amenities, urban sprawl, and community characteristics. Journal of Environmental Economics and Management, 52(2), 527-547.

Yaping, W., \& Min, Z. (2009). Urban spill over vs. local urban sprawl: Entangling landuse regulations in the urban growth of China's megacities. Land Use Policy, 26(4), 1031-1045.

Yue, W., Zhang, L., \& Liu, Y. (2016). Measuring sprawl in large Chinese cities along the Yangtze River via combined single and multidimensional metrics. Habitat International, 57, 43-52. 